A CENTENNIAL BOOK

One hundred books

published between 1990 and 1995

bear this special imprint of

the University of California Press.

We have chosen each Centennial Book

as an example of the Press's finest

publishing and bookmaking traditions

as we celebrate the beginning of

our second century.

UNIVERSITY OF CALIFORNIA PRESS

Founded in 1893 

A Critic Writes

ESSAYS bY REYNER BANHAM 


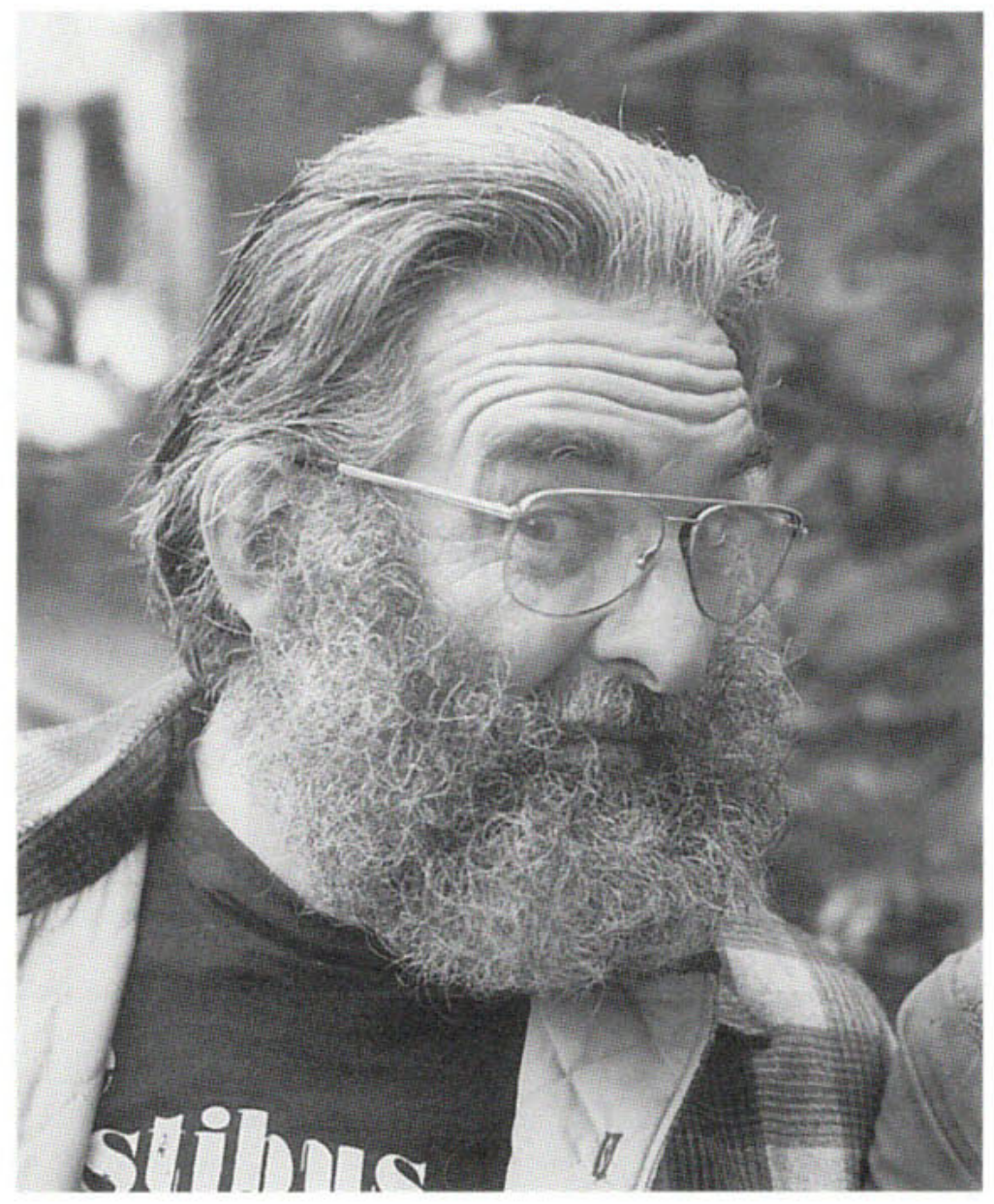

Reyner Banham in the 1980s. Photo by Bud Jacobs. 


\title{
A Critic Writes
}

\section{ESSAYS by REYNER BANHAM}

\author{
SELECTED BY Mary Banham \\ Paul Barker \\ Sutherland Lyall \\ Cedric Price
}

Foreword by Peter Hall

UNIVERSITY OF CALIFORNIA PRESS

Berkeley Los Angeles London 
Published with the assistance of

a grant from the Graham Foundation

for Advanced Studies in the Fine Arts

University of California Press

Berkeley and Los Angeles, California

University of California Press

London, England

Copyright $@ 1996$ by Mary Banham

Library of Congress Cataloging-in-Publication Data

Banham, Reyner.

A critic writes : essays by Reyner Banham / selected by Mary Banham ... [et al.].

p. $\mathbf{c m}$.

Includes bibliographical references and index.

ISBN 0-520-08855-7 (alk, paper)

1. Design-History-20th century. 2. Modernism (Art)

3. Architecture. 4. Art. I. Banham, Mary. II. Title.

NK1390.B28 1996

$745.2-\mathrm{dc} 20$

96-14255

CIP

Printed in the United States of America

$\begin{array}{lllllllll}1 & 2 & 3 & 4 & 5 & 6 & 7 & 8 & 9\end{array}$

The paper used in this publication meets the minimum requirements of American National Standard for Information Sciences-Permanence of Paper for Printed Library Materials, ANSI Z39.48-1984 